\title{
Predicon of Wave-induced Liquefaction using Artificial Neural Network and Wide Genetic Algorithm
}

\author{
Dwi Kristianto ${ }^{\mathrm{a} 1}$, Chastine Fatichah ${ }^{\mathrm{b} 2}$, Bilqis Amaliah ${ }^{\mathrm{b} 3}$, Kriyo Sambodho ${ }^{\mathrm{b} 4}$ \\ aPostgraduate Program of Informatics Engineering Institut Teknologi Sepuluh Nopember \\ Surabaya, Indonesia \\ 1dwi15@mhs.if.its.ac.id \\ bInstitut Teknologi Sepuluh Nopember Surabaya, Indonesia \\ Kampus ITS Keputih, Sukolilo, Surabaya, 60111, Jawa Timur \\ 2chastine@cs.its.ac.id \\ 3bilais@cs.its.ac.id \\ 4k_sambodho@oe.its.ac.id
}

\begin{abstract}
Abstrak
Kerumitan solusi analitis dan numerik untuk pemodelan likuafaksi, pengujian laboratorium yang berulang dan observasi lapangan yang mahal, telah membuka peluang untuk mengembangkan pemodelan prediksi likuafaksi induksi gelombang yang sederhana, praktis, murah dan valid. Dalam studi ini, pemodelan regresi Artificial Neural Network (ANN) digunakan untuk memprediksi kedalaman likuafaksi. Pelatihan ANN menggunakan Genetic Algorithm (GA) yang telah dimodifikasi yang disebut sebagai Wide GA (WGA). WGA bertujuan untuk meningkatkan akurasi prediksi ANN dan terhindar dari kelemahan Back Propagation seperti konvergensi dini dan local optimum. WGA juga bertujuan untuk menghindari kelemahan GA yaitu keragaman populasi yang rendah dan cakupan pencarian sempit. Operasi kunci WGA yang Wide Tournament Selection, Multi-Parent BLX- $\alpha$ Crossover, Agregate Mate Pool Mutation dan Direct Fresh MutationCrossover. Akurasi prediksi ANN diukur dengan Median APE (MdAPE). Solusi global optimum WGA adalah konfigurasi bobot koneksi ANN yang terbaik dengan MdAPE terkecil.
\end{abstract}

Kata kunci: Likuafaksi akibat Gelombang, Prediksi Likuafaksi Tanah, Algoritma Genetika Lebar, Jaringan Saraf Tiruan, Propagasi Balik.

\begin{abstract}
The hassle of analytical and numerical solution for liquefaction modeling, repetitive laboratory testing and expensive field observations, have opened opportunities to develop simple, practical, inexpensive and valid prediction of wave-induced liquefaction. In this study, Artificial Neural Network (ANN) regression modeling is used to predict the depth of liquefaction. Despite of using Back Propagation (BP) to train ANN, a modified Genetic Algorithm (called as Wide GA, WGA) is used as ANN training method to improve ANN prediction accuracy and to overcome BP weaknesses such as premature convergence and local optimum. WGA also aim to avoid conventional GA weaknesses such as low population diversity and narrow search coverage. Key WGA operations are Wide Tournament Selection, Multi-Parent BLX-a Crossover, Aggregate Mate Pool Mutation and Direct Fresh Mutation-Crossover. ANN prediction accuracy measured by Median APE (MdAPE). Global optimum solution of WGA is best ANN connections weights configuration with smallest MdAPE.
\end{abstract}

Keywords: Wave-induced Liquefaction, Prediction of Soil Liquefaction, Wide Genetic Algorithm, Artificial Neural Network, Back Propagation.

\section{Introduction}

Since 1970, the research works related with liquefaction prediction have been started. If Soil Liquefaction occurs, soil may undergo settlement then the structures lay above saturated soil 
ground may experience foundation failure. Numerical model deals with liquefaction is quite complicated, requires validation with laboratory testing and need expensive field inspections. A new model has been proposed to predict Liquefaction with Artificial Neural Network (ANN) and Simple Genetic Algorithm (SGA) [1] [2].

ANN is selected among many other Artificial Inteligence (AI) methods, because ANN able to model the interaction of parallel computing on the brain through the learning process of the data [3]. Back Propagation (BP) is one of widely used training method for ANN but it has some weaknesses which is BP can be trapped into local optimum (local minima) problem and premature convergence [4]. Most BP training process using very small learning rate constant which define the step of solution search. BP global optimum can only be achieved when the starting point is near to global minima which is rare (See Fig.1). Genetic Algorithm (GA) is an optimization method that mimics evolution process in nature [5]. GA has been used in numerous field of science and also has been used in ANN training process [1]. GA used in this study has been modified to improve ANN prediction accuracy.

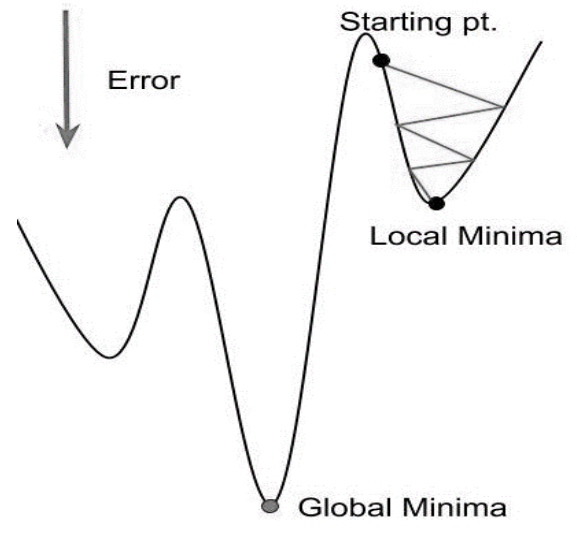

Figure 1. Back Propagation may trapped into local optimum

This paper contains five parts with introduction and literature reviews is in part one and part two, respectively. Part three discuss about the proposed new methodology. Part four is focused on discussion about empirical study related with selected topic and finally, part five is the conclusion of the findings.

\section{Literature Review}

\subsection{Wave-induced Liquefaction}

Phenomena of wave-induced liquefaction is marked by the increasing incidence of pressure load on the soil ground that exceeds the capacity of the soil particles pressure due to cyclic loading waves in coastal waters. When liquefaction occurred, the soil lost its strength. The soil strength really depend on the capability of soil to withstand cyclic loading during earthquakes or wave actions. Liquefaction condition can be formulated as Safety Factor $\left(F_{s}\right)$ below [6] :

$$
F_{S}=\frac{C R R}{C S R}
$$

CRR (Cyclic Resistance Ratio) or liquefaction resistance is the soil capacity due to cyclic load. CSR (Cyclic Stress Ratio) is the loads on the ground, that could lead to liquefaction. CRR and CSR formulated as follow [7] :

$$
\begin{aligned}
& C R R=\frac{\tau_{v h, l}}{\sigma_{v}^{\prime}}=0.0019 D_{r} \frac{1+2 K_{0}}{3} \\
& C S R=\frac{\tau_{v h}}{\sigma_{v}^{\prime}}=\frac{2 \pi}{\rho^{\prime} g} \frac{P_{0}}{L} e^{-2 \pi \frac{Z}{L}}
\end{aligned}
$$

Liquefaction will be happened when $F_{S}<=1$, then $z$ can be computed as :

$$
z=-\ln \left(\frac{0.0019 D_{r} \frac{1+2 K_{0}}{3}}{\frac{2 \pi}{\rho^{\prime} g} \frac{P_{0}}{L}}\right) \frac{L}{2 \pi}
$$




$$
\begin{aligned}
& P_{0}=\rho_{w} g \frac{H}{2} \frac{1}{\cosh \left(2 \pi \frac{d}{L}\right)} \\
& L=\frac{g T^{2}}{2 \pi} \tanh \left(\frac{2 \pi d}{L}\right)
\end{aligned}
$$

Where $\tau_{v h, l}=$ cyclic shear stress or cyclic mobility, $D_{r}=$ relative density constant, $K_{0}=$ earth pressure at rest constants, $\tau_{v h}=$ soil shear stress, $\sigma_{v}^{\prime}=$ vertical effective overburden pressure, $z=$ soil liquefaction depth, $g=$ gravity acceleration, $P_{0}=$ pressure at sea bottom, $\rho^{\prime}=$ submerged unit mass of soil, $\rho_{w}=$ water unit mass, $L=$ wave length, $H=$ wave height, $d=$ water depth and $T=$ wave periode. Sumer suggest Relative Density $\left(D_{r}\right)$ constants by soil category at Table 1 [8]. Jaky suggest Earth Pressure at Rest $\left(K_{0}\right)$ constants by soil type at Table 2 [9].

Table 1. Relative Density $\left(D_{r}\right)$ constants

Table 2. Earth Pressure at Rest $\left(K_{0}\right)$ constants

\begin{tabular}{lc}
\hline \multicolumn{1}{c}{ Soil Category } & $\boldsymbol{D}_{\boldsymbol{r}}$ \\
\hline Very Loose & $0.00-0.15$ \\
Loose & $0.15-0.35$ \\
Medium & $0.35-0.65$ \\
Dense & $0.65-0.85$ \\
Very Dense & $0.85-1.00$ \\
\hline
\end{tabular}

\begin{tabular}{lc}
\hline \multicolumn{1}{c}{ Soil Type } & $\boldsymbol{K}_{\mathbf{0}}$ \\
\hline Sandy Clay & $0.25-0.42$ \\
Silt & $0.42-0.54$ \\
Sand Dense & $0.25-0.67$ \\
Sand Coarse & 0.18 \\
Sand Fine-grained & 0.33
\end{tabular}

\subsection{Artificial Neural Network}

ANN defined as a nonlinear complex learning system occur in a network of neurons. Although Back Propagation (BP) is one of most widely used learning method for ANN, it can be trapped to a local optimum [10]. For each predicted results $\hat{y}$ to $y$, there migth be a difference noted as $y-\hat{y}$ which is referred to as residual values, error estimation or prediction errors. Median Absolute Percentage Error (MdAPE) is used to determine the performance of the ANN prediction, using the formula as follows :

$$
\text { MdAPE }=\operatorname{median}_{i=1, n}\left(\left|\frac{y-\hat{y}}{y}\right| \cdot 100\right)
$$

If the dataset has an output $y$ which its value near to zero, then MdAPE value become very large that will reduce the ANN performance. ANN performance may also decreased when each attribute in the dataset has value that is very much different in amplitude. MinMax normalization method is used to avoid these conditions and formulated as follows [11]:

$$
\begin{aligned}
& S=S_{\text {low }}+\left(S_{\text {high }}-S_{\text {low }}\right) \times \frac{A-A_{\text {min }}}{A_{\text {max }}-A_{\text {min }}} \\
& A=A_{\text {min }}+\left(A_{\text {max }}-A_{\text {min }}\right) \times \frac{S-S_{\text {low }}}{S_{\text {high }}-S_{\text {low }}}
\end{aligned}
$$

Where $A=$ original data, $A_{\min }=$ minimum value of original data, $A_{\max }=$ maximum value of original data, $S=$ normalized data, $S_{\text {high }}=$ highest value of normalized data, $S_{\text {low }}=$ lowest value of normalized data. De-normalization technique is used to restore the predicted values into the initial scale (Eq.9). In this study, value of $S_{\text {low }}=0.4$ and $S_{\text {high }}=0.9$ will be used to avoid large MdAPE values.

Rectified Linear Units (ReLU) is used to overcome constant output of activation functions, formulated as follows [12]:

$$
y=\left\{\begin{array}{l}
x, x \geq 0 \\
0, x<0
\end{array}\right.
$$

$x$ is input and $y$ is output of ReLU activation function. An algorithm is proposed by Dhiel to normalize all of the ANN connections weight to improve the performance of activation function being used above [13].

\subsection{Genetic Algorithm (GA)}

GA begins by generating the initial population contains a number of genes [5]. Each gene represents a solution that has been encoded. GA is mainly composed of a selection, crossover and mutation operation. The GA evolution stop when it reaches certain number of iteration 
(epoch) or achieving small error (convergence). GA has some constants to be determined in advance, i.e.: $P_{s}$ (population size), $P_{c r}$ (crossover probability $[0,1]$ ), and $P_{m}$ (mutation probability $[0,1])$. Darrell Whitley proposed Steady State GA [14], it has a small and fixed (steady) population number also it introduce replacement operation.

Tournament selection operation starts by selecting pair-wise genes randomly, compare the fitness values, choosing one best gene and put it into mate pool. It is repeated $N$-times depend on crossover requirement. If $N=2$, it's called as a binary tournament. Some references recommended that the value of $N>2$ to reduce the pressure of finding just the best genes alone [15].

Blend Alpha Crossover (BLX- $\alpha$ ) is crossover operation between 2 parent. It starts by randomly select two parent $x^{1}$ and $x^{2}$ from the population, then $i^{\text {th }}$ offspring allele value is randomly chosen from uniformly distributed interval of $\left[X_{i}^{1}, X_{i}^{2}\right]$ where :

$$
\begin{aligned}
& X_{i}^{1}=\min \left(x_{i}^{1}, x_{i}^{2}\right)-\alpha * d_{i} \\
& X_{i}^{2}=\max \left(x_{i}^{1}, x_{i}^{2}\right)-\alpha * d_{i} \\
& d_{i}=\left|x_{i}^{1}-x_{i}^{2}\right|
\end{aligned}
$$

$x_{i}^{1}$ and $x_{i}^{2}$ are $i^{\text {th }}$ allele value of parent $x^{1}$ and $x^{2}, \alpha$ is a positive parameter [0,1]. Picek suggested $\alpha=0.5$ [16]. If $\alpha=0$, crossover operation become more exploitative. If bigger $\alpha$ is used $(0<\alpha<$ 1 ), then crossover operation become more explorative (See Fig.2). Several previous studies indicate that crossover using multiple parent were able to improve the performance of GA [17] [18].

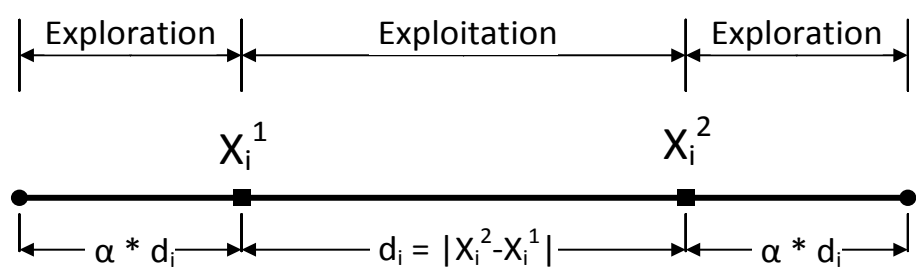

Figure 2. Exploitation and exploration of BLX- $\alpha$ crossover

Yoon and Kim proposed Fine Mutation (FM), a mutation operation methods inspired by Gaussian mutation method, formulated as follows [19]:

$$
z_{i}=z_{i}+N d\left(0,\left|x_{i}-y_{i}\right|\right)
$$

$x_{i}$ is $i^{\text {th }}$ allele of parent $x, y_{i}$ is $i^{\text {th }}$ allele of parent $y, z_{i}$ is $i^{\text {ith }}$ allele of offspring $z$ and $N d$ is normal distribution with a standard deviation of $\left|x_{i}-y_{i}\right|$.

\subsection{Hybrid ANN-GA}

There are enormous studies already conducted on the use of optimization methods in ANN training process replacing BP [20] [21] [22]. The weight of each ANN connections are encoded into a gene. Each connection weights are real numbers, so ANN-GA genes are also real numbers. ANN-GA hybridization objective is doing a global optimization of the ANN connection weights. GA have broader solution search coverage compared to BP, so it can avoid local optimum and premature convergence. GA may improve ANN performance which is maximizing accuracy and minimizing prediction error.

\section{Proposed Methodology}

The methodology proposed in this study will be called as Wide Genetic Algorithm (WGA) which is a modified version of GA that will be used to optimize the weight of each ANN connections. The WGA evolutionary iteration will stop when the ANN configuration with the lowest prediction error has been found. Fig. 3 show the flowchart of ANN training process using WGA. 


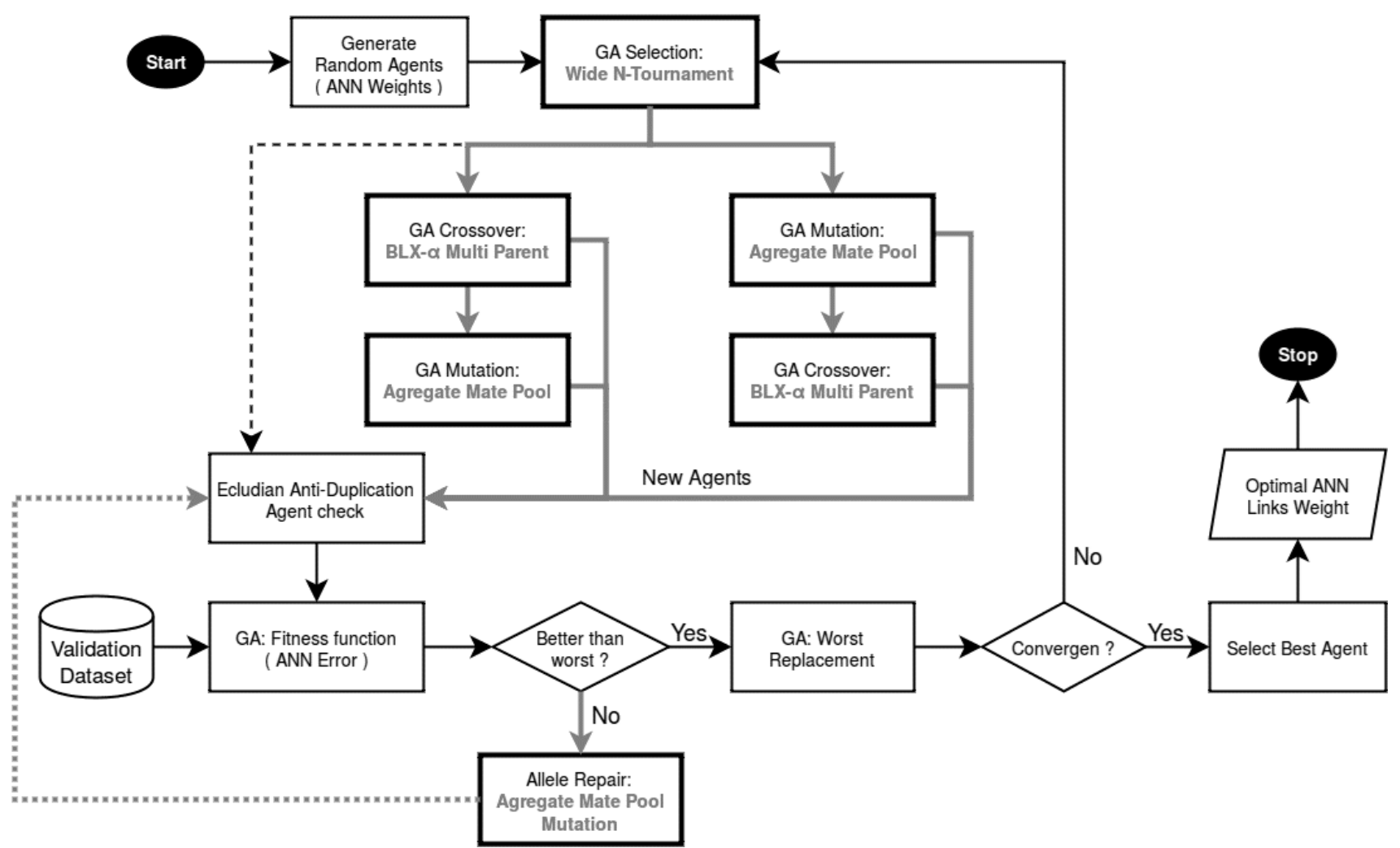

Figure 3. ANN training using WGA

\subsection{Wide Tournament Selection}

In general, the selection operation in conventional GA provides considerable big pressure to pick only the best genes, for example elitist selection method [15]. Too much selection pressure may decrease population diversity, narrowing the search coverage and can be trapped into local optimum and premature convergence. In the case of Tournament Selection, random selection of 2 genes can also increase the pressure selection. Based on the above conditions, this study proposed Wide Tournament Selection (WTS) which automatically include the worst gene from the population. WTS starts with ascending sorting based on gene fitness function then continue with choosing 4 genes randomly and adding 1 worst gene from the population (See Fig.4). Ascending sorting is needed to locate the worst gen.

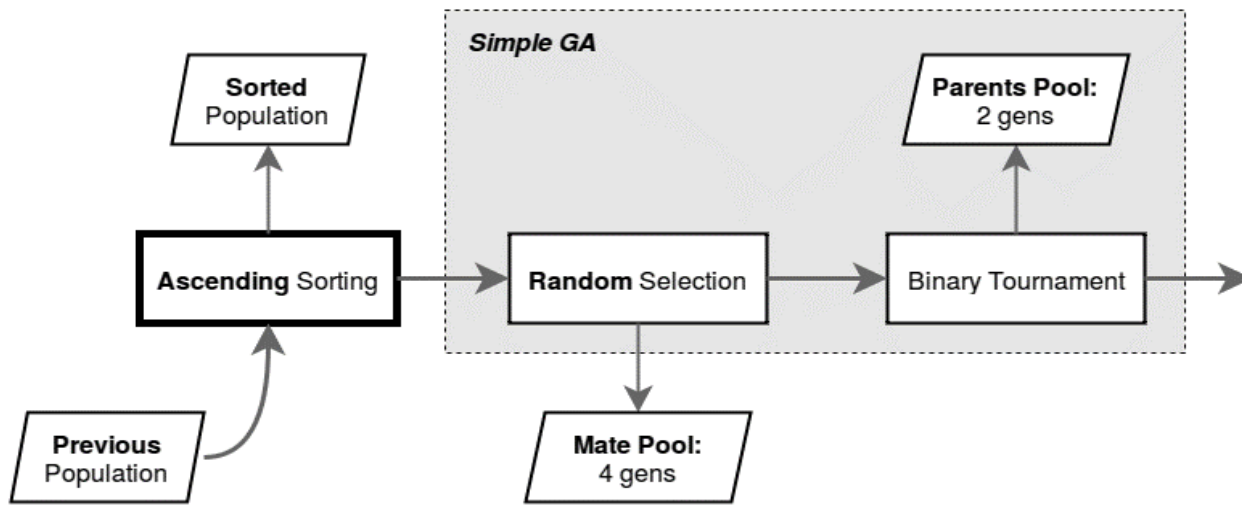

Figure 4. Wide Tournament selection flowchart

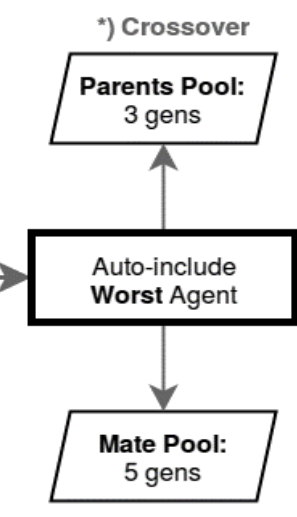

*) Mutation

\subsection{Multi Parent BLX- $\alpha$ Crossover}

Additional parent in the crossover operation can reduce the pressure in the selection process, increasing the diversity of the population and avoid incest [17] [18]. Multi Parent BLX- $\alpha$ crossover utilize worst gene which is selected by Wide Tournament selection operation above. The addition 
of the worst gene aim to enhance exploration efforts to search in wider coverage. Eq.15-17 is modification of Eq.11-13 to include the worst gene.

$$
\begin{aligned}
& X_{i}^{1}=\min \left(x_{i}^{1}, x_{i}^{2}, x_{i}^{\mathrm{w}}\right)-\alpha_{c} * d_{i} \\
& X_{i}^{2}=\max \left(x_{i}^{1}, x_{i}^{2}, x_{i}^{\mathrm{w}}\right)-\alpha_{c} * d_{i} \\
& d_{i}=\left|\max \left(x_{i}^{1}, x_{i}^{2}, x_{i}^{\mathrm{w}}\right)-\min \left(x_{i}^{1}, x_{i}^{2}, x_{i}^{\mathrm{w}}\right)\right|
\end{aligned}
$$

$x_{i}^{\mathrm{w}}$ is $i^{\text {th }}$ allele value of worst gene $x^{\mathrm{w}}$. $\alpha_{c}$ is constant $[0,1], \alpha_{c}=0.2$ is used.

\subsection{Aggregate Mate Pool Mutation}

Conventional GA mutation use only an absolute constant value for all GA evolutions which may reduce its adaptability to iteration convergence. Aggregate Mate Pool Mutation (AMPM) aims to leverage the parents value range for adaptive mutation values. Inspired by Fine Mutation (FM) [19], AMPM using not just 2 reference genes, but 5 reference genes in mutation pool which is selected by Wide Tournament Selection operation (Fig.4). These factor may lead to better search exploration and avoid local optimum easily.

\subsection{Direct Fresh Mutation-Crossover}

In the conventional GA, crossover and mutation operations carried out with certain probabilities. These probabilities may lead to ineffectiveness of each evolution in GA, which may only execute recombination or mutation operation. It is very possible where a mutation operation can be followed by a process of recombination only. To overcome this, a new technique is proposed that executes the recombination-mutation and mutation-recombination operations in parallel. The purpose of this technique to improve the effectiveness of each iteration of WGA evolution.

\section{Empirical Study}

Empirical study has been done by conducted benchmark experiments to ANN-BP, ANN-GA and ANN-WGA. Each ANN training method tested with 5 independent experiments and 1000 training iterations for each independent experiments. ANN-BP tested with learning rate $=0.01$ and learning momentum $=0.5$ and $\mathrm{K}$-folds $=7$. ANN-GA tested with population size $=20$, crossover probability $=0.5$ and mutation probability $=0.2$. ANN-WGA tested with population size $=20$. The data used in this study are gathered from previously published research [1] [2][1]. There are 7 syntetic generated dataset, its ranging from 1125 to 2520 rows of data. Each dataset divided into 2 big parts, first part is $75 \%$ of dataset used as training data and the rest $25 \%$ of dataset used as testing data. Some sample of dataset can be seen at Table 3.

Table 3. Dataset Sample

\begin{tabular}{cccccc}
\hline & \multicolumn{3}{c}{ Input } & \multicolumn{2}{c}{ Output } \\
\cline { 1 - 5 } & CSR & \multicolumn{2}{c}{ CRR } & Z \\
\cline { 1 - 5 } T & d & H & K0 & Dr & \\
\cline { 1 - 5 } 15 & 30 & 25 & 0.2 & 0.65 & 212.94 \\
14 & 10 & 5 & 0.2 & 0.65 & 103.33 \\
16 & 30 & 20 & 0.18 & 0.65 & 220.53 \\
14 & 20 & 10 & 0.16 & 0.75 & 146.35 \\
13 & 10 & 5 & 0.2 & 0.75 & 93.82 \\
12 & 50 & 15 & 0.16 & 0.75 & 151.86 \\
16 & 10 & 5 & 0.18 & 0.65 & 116.92 \\
13 & 50 & 20 & 0.2 & 0.85 & 176.42 \\
15 & 30 & 20 & 0.16 & 0.85 & 196.81 \\
13 & 70 & 20 & 0.16 & 0.85 & 174.77 \\
16 & 30 & 25 & 0.16 & 0.75 & 224.96 \\
16 & 70 & 10 & 0.2 & 0.85 & 205.81 \\
\hline
\end{tabular}

The ANN architecture that will be used in this study is dual hidden layers with single output node (later coded as 5:9:7:1), with has 5 input node, 9 hidden node +1 bias at first hidden layer, 7 
hidden node +1 bias at second hidden layer and 1 output node. The ANN architecture can be found at Fig. 5 below.

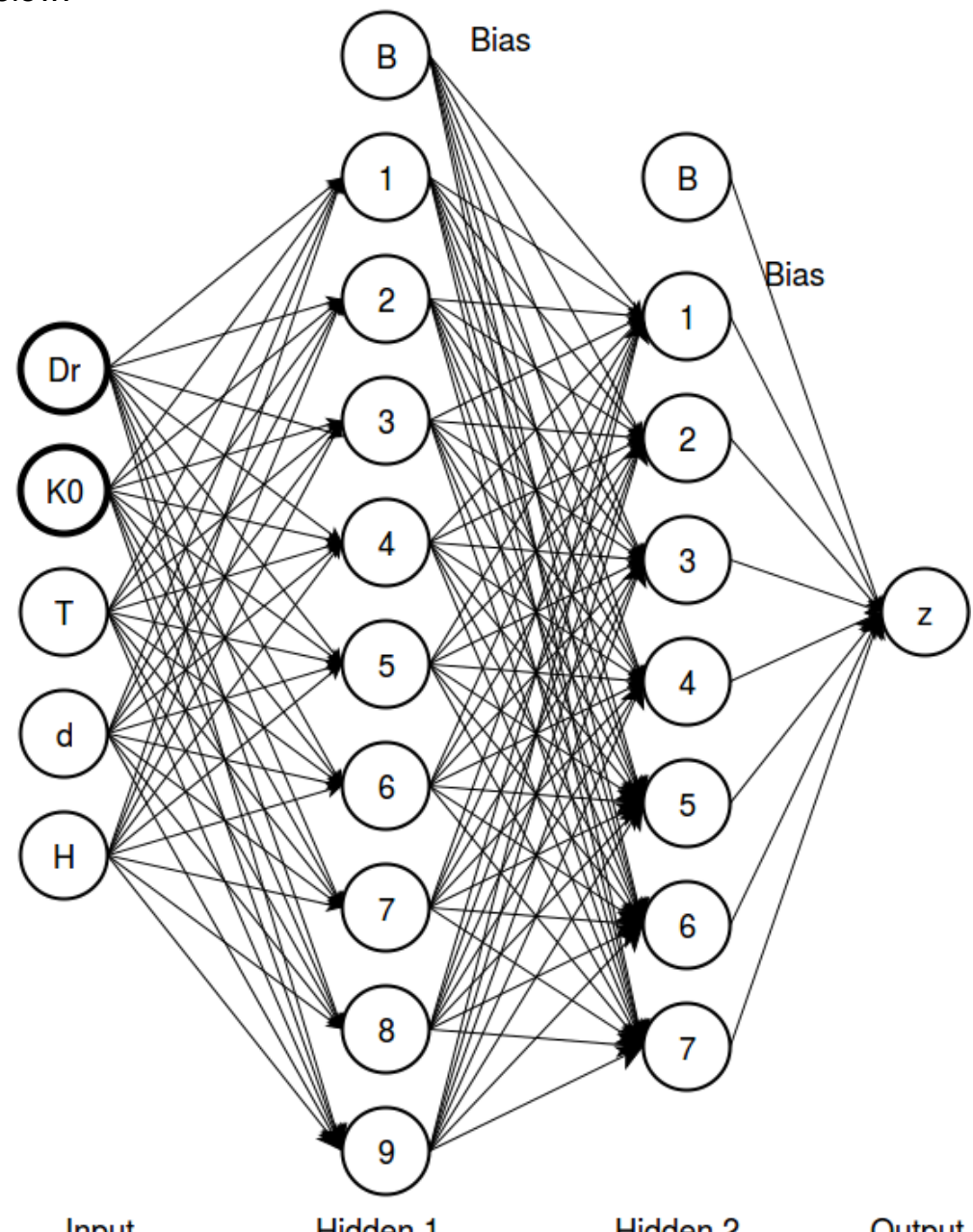

Figure 5. ANN architecture

Summary results of empirical study results can be seen at Table 4 and scattered diagrams between prediction and dataset can be seen at Fig.6. The experiments are conducted to show the performance of WGA in the training process of ANN.

Table 4. Summary Results of Empirical Study

\begin{tabular}{cccccccc}
\hline \multirow{2}{*}{ Dataset } & Total & Train & Test & $\begin{array}{c}\text { ANN } \\
\text { Arch }\end{array}$ & ANN-BP & $\begin{array}{c}\text { ANN- } \\
\text { GA }\end{array}$ & $\begin{array}{c}\text { ANN- } \\
\text { WGA }\end{array}$ \\
\hline Liquefaction Dataset 1 & 1125 & 844 & 281 & $5: 9: 7: 1$ & 5.624 & 4.404 & 3.352 \\
Liquefaction Dataset 2 & 1350 & 1013 & 337 & $5: 9: 7: 1$ & 4.880 & 4.880 & 3.487 \\
Liquefaction Dataset 3 & 2520 & 1890 & 630 & $5: 9: 7: 1$ & 4.377 & 3.085 & 2.289 \\
Liquefaction Dataset 4 & 1200 & 900 & 300 & $5: 9: 7: 1$ & 6.509 & 6.075 & 3.730 \\
Liquefaction Dataset 5 & 1800 & 1350 & 450 & $5: 9: 7: 1$ & 4.161 & 3.625 & 2.733 \\
Liquefaction Dataset 6 & 2100 & 1575 & 525 & $5: 9: 7: 1$ & 3.945 & 3.100 & 2.080 \\
Liquefaction Dataset 7 & 1152 & 864 & 288 & $5: 9: 7: 1$ & 3.327 & 3.527 & 2.707 \\
\hline \multicolumn{2}{c}{ Average MdAPE of All datasets } & & 4.689 & 4.100 & 2.911 \\
\hline
\end{tabular}

Remark: Total, Train and Test are number of data rows.

From Table 4, the experiment results show that ANN-WGA can perform roughly 1.5 times better than other training methods. For all of 7 soil liquefaction dataset, ANN-WGA can produce MdAPE 
below 4\%. Liquefaction Dataset 6 and 3 are two largest dataset among others and the experiment results show that it has smallest ANN-WGA MdAPE. Liquefaction Dataset 4 and 1 are two dataset which has smallest number of data and the experiment results show that it has biggest ANN-WGA MdAPE. We can conclude that bigger number of data may reduce ANN-WGA MdAPE.
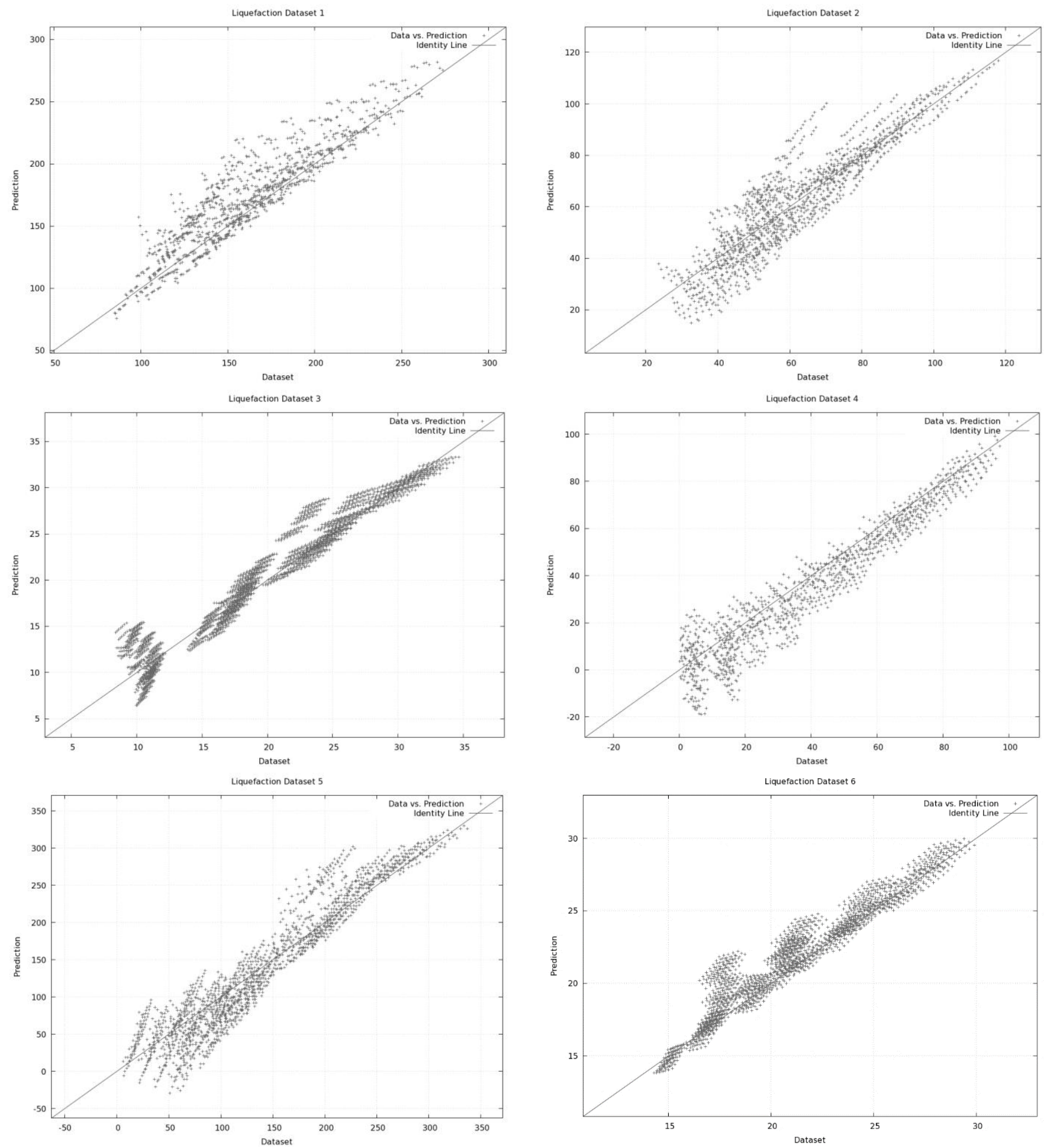


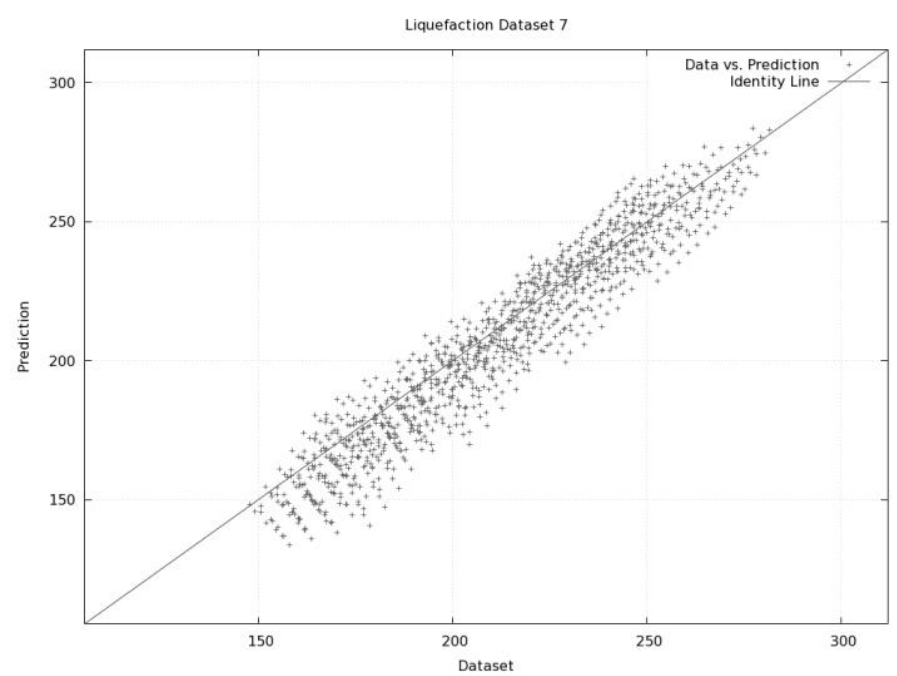

Figure 6. Scattered diagram of liquefaction prediction for dataset 1-7

\section{Conclusion}

The empirical study shows that the proposed WGA which is modifications to conventional GA, i.e.: Wide Tournament Selection, Multi-Parent BLX- $\alpha$ Crossover, Aggregate Mate Pool Mutation and Direct Fresh Mutation-Crossover can improve ANN performance to achieve better ANN prediction accuracy. Compared BP and GA as ANN training method, WGA perform 1.5 times better and can produce MdAPE below $4 \%$ for all soil liquefaction dataset being used in the experiments. These performance achieved because WGA can explore broader search space, maintain population diversity, avoid premature convergence and escape from local optimum. WGA can find best global solution for ANN which is ANN connections weight configuration with lowest MdAPE prediction error.

\section{Acknowledgements}

This research becomes possible through the financial support from Marine Reliability Availability Safety Laboratory, Marine Engineering Department, Faculty of Marine Technology, Institut Teknologi Sepuluh Nopember, Surabaya.

\section{References}

[1] D. H. Cha, H. Zhang, M. Blumenstein and D. S. Jeng, "Accurate prediction of waveinduced seabed liquefaction at shallow daepths using multi-artificial neural networks," Journal of Coastal Research, no. 56, 2009.

[2] C. C. Liao, Y. G. Z. Lin and D.-S. Jeng, "Coupling model for waves propagating over a porous seabed," Theoretical and Applied Mechanics Letters, vol. 5, no. 2, 2015.

[3] F. Gorunescu, Data Mining: Concepts, Models and Techniques, Berlin: Springer-Verlag, 2010.

[4] J. Han and M. Kamber, Data Mining: Concepts and Techniques, Elsevier, 2006.

[5] J. H. Holland, "Genetic algorithms," 2 http://www.scholarpedia.org/article/Genetic_algorithms.

[6] S. C. Tuna and S. Altun, "Modern Approaches in Soil Liquefaction Analysis," in 6th International Conference on Earthquake Geotechnical Engineering, 2015.

[7] K. Ishihara and A. Yamazaki, "Analysis of wave-induced liquefaction in seabed deposits of sand," Japanese Society of Soil Mechanics and Foundation Engineering, vol. 24, no. 3, pp. 85-100, 1984.

[8] B. M. Sumer, Liquefaction Around Marine Structures, 2014. 
[9] J. Jaky, "The coefficient of earth pressure at rest," Journal of the Society of Hungarian Architects and Engineers, vol. 78, no. 22, pp. 355-358, 1944.

[10] M. V. Shcherbakov, A. Brebels, N. L. Shcherbakova, A. P. Tyukov, T. A. Janovsky and V. A. Kamaev, "A survey of forecast error measures," World Applied Sciences Journal, no. 24, pp. 171-176, 2013.

[11] E. Ogasawara, L. C. Martinez, D. D. Oliveira, G. Zimbrão, G. L. Pappa and M. Mattoso, "Adaptive normalization: A novel data normalization approach for non-stationary time series," International Joint Conference on Neural Networks, pp. 1-8, 2010.

[12] V. Nair and G. E. Hinton, "Rectified Linear Units Improve Restricted Boltzmann Machines," Proceedings of the 27th International Conference on Machine Learning (ICML-10), pp. 807-814, 2010.

[13] P. U. Diehl, D. Neil, J. Binas, M. Cook, S.-C. Liu and M. Pfeiffer, "Fast-classifying, highaccuracy spiking deep networks through weight and threshold balancing," International Joint Conference on Neural Networks, pp. 1-8, 2015.

[14] M. Lozano, F. Herrera and J. Ramón, "Replacement strategies to preserve useful diversity in steady-state genetic algorithms," Information Sciences, vol. 178, no. 23, 2008.

[15] D. Gupta and S. Ghafir, "An overview of methods maintaining diversity in genetic algorithms," International journal of emerging technology and advanced engineering, pp. 56-60, 2012.

[16] S. Picek, D. Jakobovic and M. Golub, "On the recombination operator in the real-coded genetic algorithms," Evolutionary Computation (CEC), 2013.

[17] S. Tsutsui and A. Ghosh, "A study on the effect of multi-parent recombination in real coded genetic algorithms," Evolutionary Computation Proceedings, 1998. IEEE World Congress on Computational Intelligence., The 1998 IEEE International Conference, 1998.

[18] A. Ariyarit and M. Kanazaki, "Multi-modal distribution crossover method based on two crossing segments bounded by selected parents applied to multi-objective design optimization," Journal of Mechanical Science and Technology, 2015.

[19] Y. Yoon and Y.-H. Kim, The roles of crossover and mutation in real-coded genetic algorithms, INTECH Open Access Publisher, 2012.

[20] Y. Zhang, X. Gao and S. Katayama, "Weld appearance prediction with BP neural network improved by genetic algorithm during disk laser welding," Journal of Manufacturing Systems, 2015.

[21] A. Jarndal, "Combined genetic algorithm and neural network technique for transistor modeling," ommunications, Signal Processing, and their Applications (ICCSPA), 2015 International Conference, 2015.

[22] M. B. Takahashi, R. J. Celso and E. G. F. Núñez, "Optimization of artificial neural network by genetic algorithm for describing viral production from uniform design data," Process Biochemistry, 2015. 